\title{
Stress and ethical behaviour among South African managers
}

\author{
Ebben van Zyl \\ Department of Industrial Psychology \\ University of the Free State \\ BLOEMFONTEIN
}

\begin{abstract}
Stress and ethical behaviour among South African managers

The South African business world is increasingly characterised by wnethical behaviour and commercial crimes. Involvement of managers is contributing up to $80 \%$ of the total costs of white collar crime. In order to try to understand the situation, the current South African managerial climate is analysed.

This analysis clearly indicates that South African managers function in stressful circumstances which can give rise to unethical behaviour. A theoretical model for ethical behaviour is therefore discussed and used as a basis for practical suggestions in order to improve the situation.
\end{abstract}

\section{Introduction}

The South African business world is to an increasing extent confronted by a lack of clearly established ethical norms in its commercial practices. The frequent revelations of white-collar crime and major deceit taking place within public and private companies, coupled with recent disclosures of major fraud in private organisations, underscore the problem which the country presently faces (Wilmot, 1994:5). Fraud cases reported in South African organisations for instance increased from 33000 cases of reported fraud in 1986 to 55300 cases reported to the police in 1992. These figures represent a $67 \%$ increase over the six-year period, whereas all serious white-collar crimes have increased by $50 \%$ over the same time (De Beer, 1994)

Research (King, 1993:2; Von Lieres und Wilkau, 1993:11) has indicated that management personnel were responsible for $80 \%$ of the costs involved in whitecollar and commercial crimes. King (1993:2) states the following: "Statistics show that the largest number of fraud is committed by employees, but the fraud and comuption with the largest amounts of money involved, are committed by management". Police statistics (Schoeman, 1995) show that $25 \%$ of management in South Africa is responsible for $80 \%$ of financial or white-collar crimes. 
Stress and ethical behaviour among South African managers

Coetzee (1990:167) is of the opinion that in order to understand the unethical conduct of South African managers, the present South African management culture and accompanied high stress levels must be analysed

\section{The current South African managerial climate}

According to Coetzee (1990:167), South Africa has a unique management culture. He considers the present generation to be the first managerial group intensely involved in advanced technology. It is also the first generation involved in conflict management, unnatural interest rates and extraordinary international pressure. Competition is extreme and the rate of sacrifice mostly unfair.

Researchers (Carstens, 1989; Coetzee, 1990; Esterhuizen, 1992) believe that managers are facing two critical problems in the present circumstances prevailing in South Africa:

- The current economic situation in South Africa

Accompanying poor economic conditions in this country, the following aspects also have an impact:

- Fear of lay-off and a lower income. Lay-offs lead to a lowering in financial position and status. The self-confidence and self-image of those concerned are negatively influenced (Carstens, 1989).

- Fear that individual and/or business objectives will not be realised. To reach objectives, managers are overloaded. There are cases of managers working for up to 90 hours a week (including weekends), which means that up to $80 \%$ of non-sleeping time is spent on work activities (Van Hemert, 1990). Carstens (1989) claims that the South African highlevel employee (including managers), works an average of $15 \%$ more than his Australian equivalent. Research has also shown (Carstens, 1989:4) that the South African manager works an average of 49 hours per week, in comparison with 38,8 hours by Japanese managers, 35 hours by American managers and 31,6 hours by the German management corps.

- Unhealthy competition which leads to conflict, aggressive conduct, poor communication and low morale (Coetzee, 1990).

\section{- Political changes}

Coetzee (1990) indicated that though politics were not conducted on enterprise level in the past, it is now true that the work environment is exactly the milieu in which some workers can express and show their political power. While enterprise may traditionally have been focused on profit and service within the 
industrial environment, the additional dimension of politics may now be present (Coetzee, 1990:169).

Coetzee (1990) also indicated that apart from the already described vertical political conflict at enterprise level, lateral stress originating among managers is also present. According to him it is a fact that party political differences on management level are evident in viewpoint and policy and lead to conflict and stress.

Esterhuizen (1992:25) summarised the present South African management culture by saying that the present generation of managers are bred, in a manner of speaking, into a performing world where the prescriptions of a career and work environment have become the norm and definitely not the discretion of the individual. The individual has a prescriptive existence which coincides with high levels of stress. Unfortunately individuals must inexorably live with stress in order to survive.

Coetzee (1990:169-174) indicated that the already discussed South African management culture leads to high stress levels and the following symptoms are typical of the current South African manager: self-neglect, progressive deterioration regarding faith and religion, and marriage deterioration.

De Vries (1993:1-2) stated that the South African manager has to function in extremely difficult and stressful circumstances.

\section{The relationship between stress and unethical behaviour among managers}

Coetzee (1990:167), De Vries (1993:1-2) and Esterhuizen (1992) are of the opinion that the current economic situation in South Africa, as well as the political changes could be coupled with stress (demands exceeding managers' ability to handle them) among managers. According to these writers, the poor economic situation in particular can be coupled with overload and a fear of retrenchment among managers. Coetzee (1990) is of the opinion that a manager suffering from an overload and fear of being retrenched would work long hours, which can eventually lead to self-alienation and spiritual superficialisation. Such a person is most probably more likely to become involved in white-collar crimes (i.e. embezzlement) (Coetzee, 1990).

Van Zyl (1997) found that high stress goes hand in hand with blaming errors on innocent colleagues. Managers making mistakes most probably fear being dismissed if they admit their errors; hence the blame is passed onto innocent colleagues. Coetzee (1990) pointed out that as a result of the poor economic conditions and the accompanying fear of dismissal in the country, unhealthy 
Stress and ethical behaviour among South African managers

competition has been created among managers. Unhealthy competition normally leads to conflict, overload, poor communication and unethical behaviour (Coetzee, 1990:20).

Van Zyl (1997:5) also indicated that high stress does relate to a failure to report colleagues' violation of company policy. Erman (1994) pointed out that infringements are not always reported. One reason for this (according to Erman) is when those involved fear losing their position and/or friends (Erman, 1994:31)

Researchers agree that stressful working conditions can lead to unethical behaviour among managers. Menzel (1993), for instance, found that when managers under stress are confronted with moral decisions, preference would be given to circumstances above own discretion/judgement. Menzel (1993) further concluded that managers working in a group where little trust and group cohesion exist among group members they would be more prone to unethical behaviour. It was also found that where rules and regulations are to be followed, unethical behaviour was more likely to occur.

James and Arraba (1992) expressed the opinion that managers experiencing high stress levels are more inclined to suffer from tunnel vision, that could cloud their judgement in decision-making (including ethical decisions).

Victor and Cullen (1988) and also Cullen et al. (1992) indicated that overload, time pressure and a poor correlation between ability and task demands may lead to unethical conduct.

Van Zyl (1997) stated that social issues within the workplace have been connected with unethical behaviour - a phenomenon which may be an indication that in a stressful society managers enjoy insufficient support from supervisors and colleagues.

Erman (1994) pointed out that dentands which managers find hard to comply with, lead to rules being broken.

\section{The problem and aim of the article}

From this discussion it seems clear that the South African manager has to function in extremely difficult and stressful circumstances which can lead to unethical behaviour among managers.

The aim of this article is therefore to give a clearer picture of unethical behaviour among managers by means of a model, and to use this model as the basis of practical suggestions to improve the situation. 


\section{Theoretical model}

The research of Stead et al. (1994:58) strongly supports a person-situation explanation of ethics in which both individual and situational (organisational) factors influence the decisions made by individuals. Esterhuizen (1992:30) defined business ethics (as part of the above-mentioned approach to ethics) as the consideration of business activities and moral standards involving personal, organisational and community norms and values. A model of ethical behaviour as part of the person-situation interaction approach can be depicted as shown in Figure 1 (Stead et al., 1994:64).

Stead, Worrel and Stead's model has two important identifiable phases (see Figure 1).

\section{- The first phase}

The first phase reflects the relationship between the individual factors and the development of the person's ethical philosophy and decision ideology. Essentially, this linkage demonstrates that the ethical beliefs one holds, and the way in which these beliefs are applied, are strongly influenced by personality and background.

Individual factors include personality and socialisation aspects (Stead et al., 1994:59). Researchers have suggested three personality measures that may influence ethical behaviour - ego-strength, machiavellianism and locus of control (Trevino, 1987). Ego-strength is defined as an individual's ability to engage in self-directed activity and to manage tense situations (Trevino, 1987). Machiavellianism is a measure of deceitfulness and duplicity (Levenson, 1974). Locus of control is a measure of whether or not a person believes that his or her outcomes in life are determined by his/her own actions - internal or by luck, fate or powerful others and institutions (external) (Levenson, 1974).

Socialisation also seems to influence a person's ethical system. Researchers have identified sex role differences, religious beliefs, age, work experience and nationality as factors which may influence the ethical decisions made by individuals (Trevino, 1987).

The network of ethical norms and principles one holds constitutes one's ethical philosophy. Cavanagh et al. (1981) identified three basic ethical philosophies: The first philosophy implies utilitarianism. The central concept of utilitarianism is a belief that ethics is best applied by considering the greatest good for the greatest number. The The second philosophy implies individual rights. This philosophy focuses on protecting individual rights such as the right to perform, the right of free consent, the right to due process, etc. The third ethical philosophy implies justice. Such an ethical system stresses social justice and the opportunity for all to pursue meaning and happiness in life. Stead et al. (1994:60) 
Figure 1: Model of ethical behaviour

(Stead et al., 1994:64)

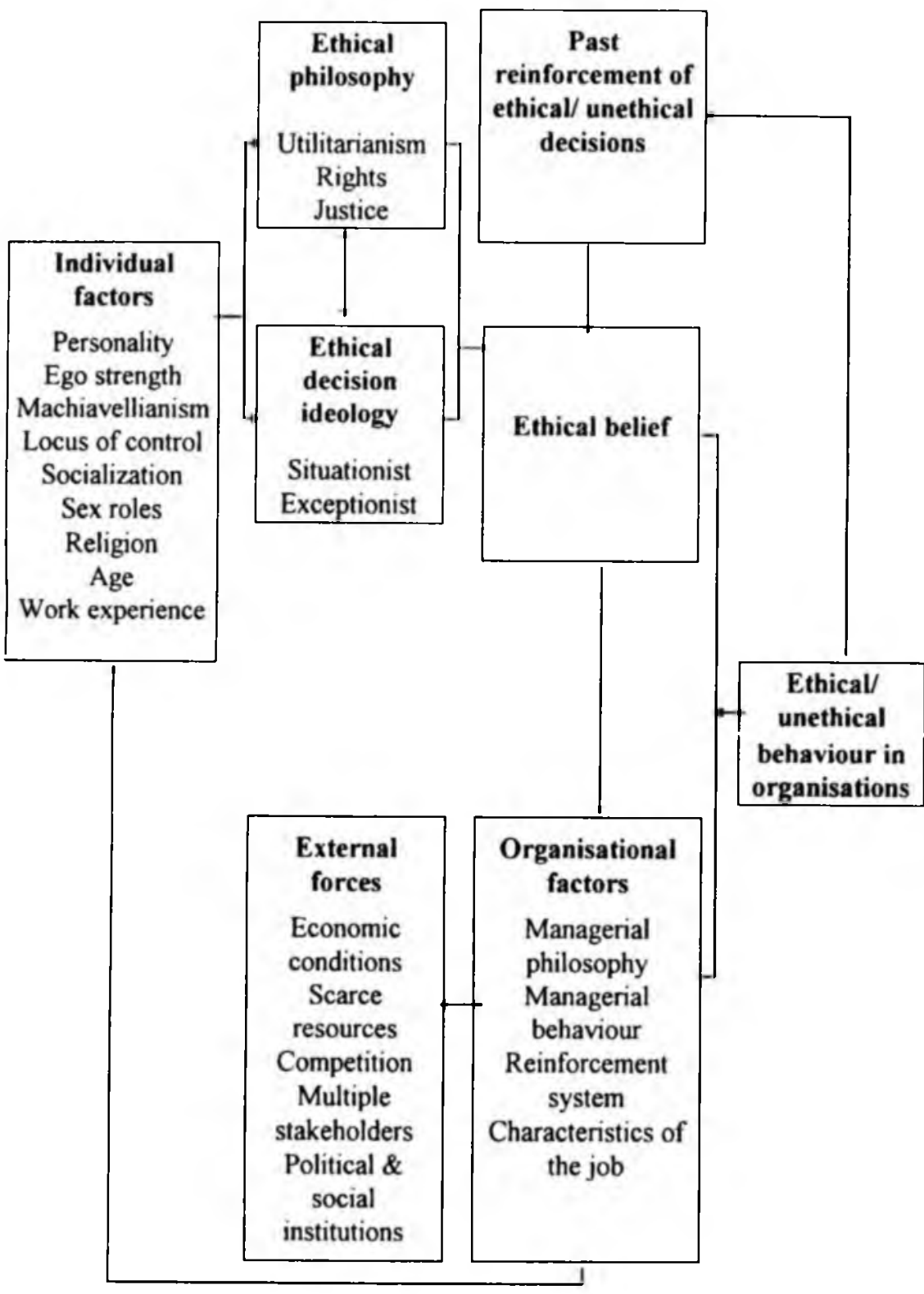


stated that most individuals allow one of these philosophies to dominate their ethical decisions, with the utilitarian philosophy being dominant among business managers.

Stead et al. (1994:60) also contended that individuals differ in terms of the moral judgement they make, and that the actions they take resulting from these moral judgements also differ. These authors refer to these differences as ethical decision ideologies and say that these are based on two dimensions. The first dimension implies idealism which depends on the degree to which an individual believes that ethical behaviour always results in good outcomes. The second dimension implies relativism - the degree to which an individual believes that moral rules are situational. Persons high in both idealism and relativism are called situationists. They reject the use of universal or individual moral principles, preferring to analyse each situation and to determine appropriate moral behaviour based on this analysis. Exceptionists, those low in both dimensions, believe in moral rules as guides, but are open to practical exceptions.

\section{- The second phase}

The second phase constitutes the organisational factors (which are affected by external forces) which influence the someone's ethical belief system. These interactions eventually lead to ethical/unethical behaviour in organisations. It must, however, be kept in mind that behaviour is usually reinforced - rewarded, punished, etc. - which in turn influences the person's ethical belief (Stead $e t a l$, 1994:60).

Regarding organisatıonal factors it seems as if the philosophies of management as well as of managerial behaviour have a major impact on the ethical behaviour of employees (Trevino, 1987). Another critical organisational variable that influences behaviour is the firm's reinforcement system. Research in ethical behaviour strongly supports the conclusion that if ethical behaviour is desired, the performance measurement, appraisal and reward systems must be modified to account for ethical behaviour. Several dimensions of the job itself may also influence the ethical behaviour of employees. Jobs involving external contacts are, for instance, believed to have more potential for ethical dilemmas than jobs with purely internal contacts (Stead et al., 1994:62). External factors can also undermine ethical behaviour as a result of their effect on the ethical philosophies of managers, the reinforcement system, etc. Poor economic conditions, resource scarcity and pressure from shareholders, for instance, may put a firm in a position of having to choose between being an ethical role model for its industry or succumbing to situational pressures and engaging in unethical practices. 
Stress and ethical behaviour among South African managers

\section{Ethics in practice}

Moral behaviour in organisations is an intricate and complex problem with important individual and circumstantial dimensions. The moral beliefs of the manager (individual dimension) and situational factors have the most important influence on the moral behaviour of managers as indicated by the model and research (Stead et al., 1994:65).

It therefore follows that in order to encourage South African managers to behave ethically, there has to be individual and also organisational (situational) intervention.

\subsection{Individual intervention}

The following single actions should be aimed at by South African managers (Coetzee, 1990:175-180; Esterhuizen, 1992:40-42):

- Recognise the symptoms of failing self-management and strive towards a turning point. If the symptoms of insufficient self-management, such as personal and religious superficialisation, become evident, managers should have the courage to acknowledge these symptoms and do something about them (Coetzee, 1990).

- Conduct personal strategic management by:

- periodically evaluating your own destiny;

- evaluating whether growth has taken place and the extent and benefits of efforts; and

- regularly evaluating yourself, especially by giving a nominated person permission to do such an evaluation (Coetzee, 1990). In this process, shortcomings and areas of neglect are timeously identified and remedial actions can be focused on (Coetzee, 1990; Esterhuizen, 1992).

- Normalisation of ambition. Using introspective honesty, managers can ask themselves whether they aspire to higher positions than their real abilities/ potential allow. According to Coetzee (1990), the organisation theory which always represents promotion graphically in terms of vertical growth is wrong. More emphasis should be placed on lateral growth, so that individuals remain on their level of competence and are not promoted to a level of incompetence.

- Managers should look afresh at their personal set of abilities and skills and focus on them. By focusing on their own ability and skills, their work load can be alleviated and efficiency and productivity can be increased. 
- Realise personal values in all aspects of life. If there is compatibility between personal ideology and work realisation, deeper satisfaction and greater personal growth can be attained more easily (Coetzee, 1990).

- Apply the principle of communality to professional life. This factor necessitates the integration of the spouse in all decisions regarding work and profession. In particular it means that the spouse should be given a say in order to create a synergy in the management of the career.

\subsection{Organisational interference}

Researchers (Coetzee, 1990; Van Zyl, 1993) agree that a sensitive employer is an important directive influence in encouraging ethical conduct in organisations. By implementing preventative maintenance and concerned supervision of the psychic well-being of managers, unnecessary stressful situations and unethical conduct can be prevented. According to Carstens (1989:11) the following can be done to prevent unethical conduct:

- Create a supporting organisational climate where support is given particularly in the form of open and regular communication between managers and personnel practitioners/psychologists. In the process problems can be identified timeously and measures to deal with the situation can be implemented proactively. Furthermore, regular discussions and lateral communication with colleagues can be helpful in discussing mutual problems and suggesting solutions.

- Create an ethical organisational climate where, amongst others, functioning takes place according to an ethical code of conduct and employees are offered ethical conduct training. Employees should in particular be informed how and when unethical behaviour should be reported, and that reporting of unethical behaviour can be "rewarded".

- Train managers to deal with difficult demands (such as overload). This will help employees and employers to adapt to difficult political and economic conditions in South Africa.

\section{Conclusion}

Owing to South Africa's high incidence of commercial crimes and the amounts of money involved, more than ever before managerial people have the responsibility of handling their high stress levels and to practise ethical norms. This can be done by addressing the problem in a multi-faceted way but with the focus on individual and organisational strategies. 
Stress and ethical behaviour among South African managers

The same intensity of focus must, however, be imposed on individual and organisational strategies in order to find solutions for relevant problems. The Scriptures tell us: "Cast your bread upon the waters, for you will find it after many days." If this viewpoint is followed, all parties concerned will realise that their own responsibilities must be met to ensure ethical conduct in work context. It also means that it is a longterm task with no immediate effects

The current economic and political situation in South Africa and the level of stress that can be caused by it, cannot possibly be changed. Individual and organisational strategies can, however, create a new frame of reference in which caring, purposeful, committed and ethical people can be part of the institutional setting. This frame of reference can contribute to the establishment of a fair, just, participatory and ethical society.

\section{References}

CARSTENS, L. 1989. Die ontwikkeling en implementering van 'n stresbeheerprogram. Bloemfontein : University of the Orange Free State. (D.Com. thesis.)

COETZEE, J. 1990 Selfbestuur. (In Van der Walt, G. red. Venster op die sakewêreld Goodwood : Nasionale Boekdrukkery. p. 167-178.)

CAVANAGH, G., MOMBERG, D \& VELASQUEZ, M. 1981. The ethics of organisational politics Academy of Management Review, 3:363-374.

CULLEN, L., VICTOR, S., STEPHENS, M. 1992 Business ethics. New Management, $7(2): 15-20$.

DE BEER, E. 1994 Stealing South Africa blind: The scourge of white-collar crime. Servamus, 87(9) 44-45.

DE VRIES, J. 1993. Bestuursetiek. Paper presented at workshop on "Werksetiek binne die Suid-Afrikaanse organisasiekonteks", held on 21 June 1993, Pretoria.

DRUMMOND, J. \& BAIN, B eds. 1994. Managing business ethics. Oxford : Butterworth.

ESTERHULZEN, W. 1992. Sake-etiek. Goodwood : Nasionale Boekdrukkery.

ERMAN, M.A. 1994. How managers unintentionally encourage corporate crime. Business and Society Review, 13:28-32.

JAMES, E. \& ARRABA, S. 1992. Ethics in the work situation. Journal of Business Ethics, 7(7): $1-7$

KING, ME. 1993. Ethics and corruption. Paper presented at conference on "Ethics and corruption", held on 14 October 1993, Johannesburg.

LEVENSON, H. 1974. Activism and powerful others Journal of Personality Assessment, 38:377-383

MENZEL, F. 1993. Beyond stress to effective management. Journal of Applied Behavioural Science, 20:141-153.

SCHOEMAN, W.S. 1995. White-collar crimes in South Africa. Discussions with Brig Schoeman on crime figures as recorded by the South African Police. Rapport, $15 \mathrm{Jan}$.

STEAD, W.E., WORREL, D.L. \& STEAD, G.S. 1994. An integrative model for understanding and managing ethical behaviour in business organisations. (In Drummond, J. \& Bain, B. eds. Managing business ethics Oxford : Butterworth. p. 58-73.)

TREVINO, L.K. 1987 Ethical decision-making in organisations. Academy of Management Review, 1(3):601-612. 
Ebben van Zyl

VAN HEMERT, S. 1990. Stres en protospanlede in die mynbedryf. Johannesburg : Rand Afrikaans University. (M.Com. dissertation.)

VAN ZYL, E.S. 1993 Business ethics in practice within South African companies. Human Resource Management, 9:30-32.

VAN ZYL, E.S. 1997. The relation between stress and ethical behaviour in a group of midlevel managers in the financial sector. Acta Criminologica, 10:30-40.

VICTOR, S \& CULLEN, L. 1988. Ethics in practice. New Management, 3(4):2-8

VON LIERES UND WILKAU, L. 1993. Etiek in die besigheidswêreld. Paper presented at workshop on "Werketiek binne die Suid-Afrikaanse organisasiekonteks", held on 21 June 1993, Pretoria

WILMOT, P.L. 1994. The prevention and detection of white collar crime. Accountancy South Africa, 4(4) 4-98 